\title{
BIOACCUMULATION, TRANSLOCATION AND PHYTOREMEDIATION BY ENDEMIC SERPENTINOPHYTE Artemisia alba TURRA.
}

\author{
*Snežana R. Branković1, Radmila M. Glišić1, Zoran Simić ${ }^{2}$ Vera R. Đekić3 ${ }^{3}$, \\ Milun M. Jovanovic ${ }^{4}$ and Marina D. Topuzović ${ }^{1}$ \\ ${ }^{1}$ University of Kragujevac, Faculty of Science, Institute of biology and ecology, \\ Radoja Domanovića 12, 34000 Kragujevac, Republic of Serbia \\ ${ }^{2}$ University of Kragujevac, Faculty of Science, Institute of chemistry, Radoja Domanovića 12, \\ 34000 Kragujevac, Republic of Serbia \\ ${ }^{3}$ Center for small grains, Save Kovačevića 31, 34000 Kragujevac, Republic of Serbia \\ ${ }^{4}$ Geological Bureau of Serbia, Rovinjska 12, 11050 Belgrade, Republic of Serbia \\ *Corresponding author; E-mail: snezana.brankovic@pmf.kg.ac.rs
}

(Received April 5th, 2019; Accepted May 5th, 2019)

\begin{abstract}
The aim of this study was to determine the concentrations of some metals $(\mathrm{Ca}, \mathrm{Mg}, \mathrm{Fe}, \mathrm{Mn}, \mathrm{Zn}, \mathrm{Ni}, \mathrm{Cr}$ ) in the soil and in the endemic serpentinophyte Artemisia alba Turra. (Artemisia lobelii All.) on one serpentine site (Central Serbia), for determination the ability of this plant species in bioaccumulation, translocation and phytoremediation of researched metals. The concentrations of $\mathrm{Ni}$ and $\mathrm{Cr}$ in the investigated soil were above remediation values, the maximum allowable concentration, as well as of prescribed limit value of substances in the soil according to regulation of Republic of Serbia. Good translocation of $\mathrm{Ca}, \mathrm{Mn}$ and $\mathrm{Zn}$ through the trees and leaves of the A. alba species, as well as the translocation and accumulation of $\mathrm{Mg}$ and $\mathrm{Ni}$ in the leaves of the investigated plant has been shown. We can consider A. alba as a potential candidate for phytoextraction and photoremediation of soils contaminated with $\mathrm{Ca}, \mathrm{Mg}$, $\mathrm{Mn}, \mathrm{Zn}$ and Ni.
\end{abstract}

Key words: metals, plants, bioaccumulation, translocation, phytoremediation

\section{INTRODUCTION}

The term "serpentine" strictly speaking refers only to the serpentine group of minerals with the general formula $\mathrm{Mg}_{3} \mathrm{Si}_{2} \mathrm{O}_{5}(\mathrm{OH})_{4}$ which are important constituents of weathered "ultramafic rocks". Serpentines are rocks that from as a result of metamorphisam or metasomatism of primary magnesium-iron silicate minerals. Ultramafic (serpentine) soils represent a category of substrates derived from ultramafic bedrock and distributed around the world. Properties commonly shared among ultramafic soils include high $\mathrm{Fe}$ and $\mathrm{Mg}$ concentrations and low $\mathrm{Al}$ and $\mathrm{Ca}$ concentrations, relatively high concentrations of $\mathrm{Cr}$, $\mathrm{Co}$ and $\mathrm{Ni}$, high magnesium-to-calcium ( $\mathrm{Mg}: \mathrm{Ca}$ ) quotients in the exchange complex and low concentrations of $\mathrm{P}$ and $\mathrm{K}$ (both total and extractable) (ECHEVARRIA, 2018). Serpentine 
substrates cover quite large areas in the Balkans, more than in other parts of Europe (BROOKS, 1987, TATIĆ and VeLJOVIĆ, 1992). They exist as large blocks or as small outcrops separated from other geological formations, in Central Bosnia and Western and Central Serbia, and extend towards North, Central and South-Eastern parts of Albania and further to the serpentine formations in the regions of Epirus and Thessaly in Greece (BANI et al. 2010).

Some factors of the serpentine soil chemistry ("serpentine syndrome") make it inhospitable environment for many plants. The potential toxic $\mathrm{Mg}$ level, $\mathrm{Ca} / \mathrm{Mg}$ imbalance, phytotoxic $\mathrm{Ni}$ level and deficiency $\mathrm{P}$ level of serpentine soils are primary reasons for serpentine soil infertility, which causes evolution of serpentine. Since the serpentine soil properties are disadvantageous for most plants, distinctive vegetation communities have evolved on serpentine soils (BROOKS, 1987). Species growing on these soils can be classified into two categories: serpentine-tolerant plants (serpentine-facultative plants) which withstand the serpentine conditions, but they are also found more widely, and often show better growth elsewhere and serpentine-endemic plants (serpentine-obligate plants) restricted exclusively to serpentine soil and are not found on other substrates (FREITAS et al., 2004). The serpentine flora of the Balkan is characterized by a relatively high degree of endemism. According to STEVANOVIĆ et al. (2003) there are 335 Balkan endemic vascular plant taxa growing on serpentine, of which 123 are obligate serpentinophytes.

The aims of this study were to determine the content of some metals $(\mathrm{Ca}, \mathrm{Mg}, \mathrm{Fe}, \mathrm{Mn}$, $\mathrm{Zn}, \mathrm{Ni}, \mathrm{Cr}$ ) in the soil and in the endemic serpentinophytes Artemisia alba Turra. (Artemisia lobelii All.) that grow on it, to determine the ability of the plant species in bioaccumulation, translocation and phytoremediation of investigated metals.

\section{MATERIALS AND METHODS}

\section{Study site}

The researched locality was located near the village of Kamenica in Central part of Serbia. This site presents a part of a much larger part of serpentine substrate, located in Western and Central Serbia, and extend towards North, Central and South-Eastern parts of Albania. The investigated site is at $352-410 \mathrm{~m}$ above sea level and is centered on $43^{\circ} 36^{\prime} 760^{\prime \prime}$ $-44^{\circ} 04^{\prime} 34^{\prime \prime} \mathrm{N}, 20^{\circ} 42^{\prime} 046^{\prime \prime}-20^{\circ} 32^{\prime} 24^{\prime \prime}$ E (read by GPS Garmin-etrex, vista HCx).

\section{Soil and plant sampling and analysis}

One serpentine locality was surveyed to collect endemic obligate serpentinophyte Artemisia alba Turra. (Artemisia lobelii All.) together with their associated soils. Six soil samples were collected from 1 to $10 \mathrm{~cm}$ depth, near roots of researched plant. This depth corresponds to the major rooting zone of the herbs and small shrubs (REEVES et al., 2007). Soil samples were initially air-dried and stone pieces were removed, sieved to $2 \mathrm{~mm}$, and stored at $4{ }^{\circ} \mathrm{C}$ until analysis. Sub-samples of $10 \mathrm{~g}$ were ground to pass a 70-mesh sieve $(<215$ $\mu \mathrm{m})$ and then oven-dried at $105^{\circ} \mathrm{C}$ for $24 \mathrm{~h}$ (Binder/Ed15053).

The determination of plant material was performed in the laboratory of the Institute of Biology and Ecology, Faculty of Science in Kragujevac, with the help of standard keys for determination: Javorka and Csapody (JAVORKA and CSAPODY, 1979), Flora of the Republic of Serbia (JosifoviĆ, 1991) and Flora Europaea (TUTIN, 1976). Voucher specimens (17483) are deposited in Herbarium of the Institute of Botany and Botanical garden "Jevremovac", University of Belgrade (BEOU). Artemisia alba is classified into Kingdom: Plantae, Subkingdom: Tracheobionta, Superdivision: Spermatophyta, Division: Magnoliophyta, Class: Magnoliopsida, Subclass: Asteridae, Order: Asterales, Family: Asteraceae, Subfamily: 
Asteroideae, Tribe: Anthemideae, Subtribe: Artemisiinae, Genus: Artemisia L., species: Artemisia alba Turra. (VALLES et al., 2003).

Identified plant material was prepared for further analysis (BRANKOVIĆ et al., 2015). In order to determine the total metal content in soil and plant material, the samples were prepared by digestion with nitric acid and hydrogen peroxide according to EPA $3050 \mathrm{~b}$ (US EPA, 1997) in relation to $\mathrm{HNO}_{3}: \mathrm{H}_{2} \mathrm{O}_{2}=5: 1$; relationship soil pattern/digestion mixture was $1: 12$. In order to check the accuracy of the applied method, blank tests and standard reference materials were used: MEES-3 (trace elements in soils) and LGC7173, for plant material. The values obtained ranged in the range of $\pm 5 \%$ of the certified values.

Seven metals (Ca, Mg, Mn, Fe, $\mathrm{Zn}, \mathrm{Ni}, \mathrm{Cr}$ ) were analyzed in soil and plant material (root, stem, leaf, whole plant). The metal concentrations in plant and soil samples were determined by inductively coupled plasma-mass atomic emission spectrometry (Perkin Elmer 3300), directly from the solution at the Institute of Chemistry, Faculty of Science in Kragujevac. The six replication of soil and plant material were determined, also mean values and standard deviation were calculated. Also, different factors as indicators of ability of the plant species in bioaccumulation, translocation and phytoremediation of researched metals were calculated on way presented in next table (Table 1).

Table 1. Formulas for calculating the factors for bioaccumulation, translocation, enrichment and apsorption coefficient

\begin{tabular}{|c|c|c|}
\hline FACTOR & FORMULAS & Elements of formula \\
\hline $\begin{array}{l}\text { Bioaccumulation factor }(\mathrm{BF}) \\
\text { (GHOSH and SING, 2005) }\end{array}$ & $\mathrm{BF}=\mathrm{C}_{\text {root }} / \mathrm{C}_{\text {soil }}$ & $\begin{array}{l}\mathrm{C}_{\text {root }} \text { - the metal concentration in the } \\
\text { plant root } \\
\mathrm{C}_{\text {soil }} \text { - the metal concentration in the } \\
\text { soil }\end{array}$ \\
\hline $\begin{array}{l}\text { Translocation factor }(\mathrm{TF}) \\
\text { (GUPTA et al. 2008) }\end{array}$ & $\begin{aligned} \mathrm{TF}_{\text {stem }} & =\mathrm{C}_{\text {stem }} / \mathrm{C}_{\text {root }} \\
\mathrm{TF}_{\text {leaf }} & =\mathrm{C}_{\text {leaf }} / \mathrm{C}_{\text {root }}\end{aligned}$ & $\begin{array}{c}\mathrm{C}_{\text {stem }} \text { - the metal concentration in the } \\
\text { plant stem }\end{array}$ \\
\hline $\begin{array}{l}\text { Enrichment factor }(\mathrm{EF}) \\
\text { (GHOSH and SING, 2005) }\end{array}$ & $\begin{array}{l}\mathrm{EF}_{\text {stem }}=\mathrm{C}_{\text {stem }} / \mathrm{C}_{\text {soil }} \\
\mathrm{EF}_{\text {leaf }}=\mathrm{C}_{\text {leaf }} / \mathrm{C}_{\text {soil }}\end{array}$ & $\begin{array}{c}\mathrm{C}_{\text {leaf }} \text { - the metal concentration in the } \\
\text { plant leaf }\end{array}$ \\
\hline $\begin{array}{l}\text { Apsorption coefficient }(\mathrm{AC}) \\
\text { (KABATA-PENDIAS, 2001) }\end{array}$ & $\mathrm{AC}=\mathrm{C}_{\text {plant }} / \mathrm{C}_{\text {soil }}$ & $\begin{array}{c}\mathrm{C}_{\text {plant }} \text { - the metal concentration in the } \\
\text { whole plant }\end{array}$ \\
\hline
\end{tabular}

Also, the ratio between metal concentration of aboveground and underground organs as well as leaf and stem metal concentration were determined. The content of metals in soil and plant materials were expressed in $\mathrm{mg} \mathrm{kg}^{-1}$ of dry matter $\left(\mathrm{mg} \mathrm{kg}^{-1}\right.$ d.m.).

\section{RESULTS}

The mean concentrations of $\mathrm{Ca}, \mathrm{Mg}, \mathrm{Mn}, \mathrm{Fe}, \mathrm{Zn}, \mathrm{Ni}$ and $\mathrm{Cr}\left(\mathrm{mgkg}^{-1} \mathrm{~d} . \mathrm{m}\right.$.) in soil and species $A$. alba are shown in Table 2.

Generally, results of our study showed that the mean concentrations of investigated metals were far higher in the soil samples than those calculated for the same metals in plant samples (except for $\mathrm{Ca}$ ).

The BF, an index of ability of the plant to accumulate a metal, with respect to its concentration in the soil substrate is shown in Table 3. The content of $\mathrm{Ca}$ in root of $A$. alba was higher than its content in soil $(\mathrm{BF}>1$ for $\mathrm{Ca})$.

The EF (ratio of a metal concentration in a plant aboveground part to its concentration in soil) higher than 1 for $\mathrm{Ca}$ was found at stem and leaf, and higher than 1 for $\mathrm{Zn}$ at leaf of investigated plant species. 
Table 2. The mean concentrations of $\mathrm{Ca}, \mathrm{Mg}, \mathrm{Mn}, \mathrm{Fe}, \mathrm{Zn}, \mathrm{Ni}$ and $\mathrm{Cr}\left(\mathrm{mg} \mathrm{kg}^{-1} \mathrm{~d}\right.$. m.) in soil and in Artemisia alba plant parts.

\begin{tabular}{|c|c|c|c|c|c|}
\hline \multirow{2}{*}{ METAL } & \multirow{2}{*}{ SOIL } & \multicolumn{4}{|c|}{ PLANT } \\
\hline & & root & stem & leaf & whole plant \\
\hline $\mathbf{C a}$ & $1109.08 \pm 6.1$ & $5068.83 \pm 54.01$ & $3401.33 \pm 434.95$ & $7341.33 \pm 7.28$ & $5270.50 \pm 1678.54$ \\
\hline Mg & $59603.59 \pm 312.0$ & $2460.50 \pm 17.00$ & $3382.17 \pm 12.72$ & $8922.83 \pm 17.19$ & $4921.83 \pm 2936.83$ \\
\hline Mn & $288.86 \pm 6.4$ & $19.38 \pm 0.39$ & $10.68 \pm 0.48$ & $28.22 \pm 0.61$ & $19.43 \pm 7.38$ \\
\hline $\mathbf{F e}$ & $35709.91 \pm 320.9$ & $214.00 \pm 2.19$ & $415.67 \pm 1.21$ & $318.83 \pm 1.17$ & $316.17 \pm 84.75$ \\
\hline $\mathbf{Z n}$ & $23.12 \pm 0.2$ & $11.53 \pm 0.30$ & $18.43 \pm 0.34$ & $28.60 \pm 0.51$ & $19.52 \pm 7.22$ \\
\hline $\mathbf{N i}$ & $931.49 \pm 23.7$ & $32.93 \pm 0.69$ & $35.48 \pm 0.50$ & $93.52 \pm 0.75$ & $53.98 \pm 28.80$ \\
\hline $\mathrm{Cr}$ & $485.24 \pm 10.7$ & $5.42 \pm 0.31$ & $2.75 \pm 0.15$ & $9.18 \pm 0.15$ & $5.78 \pm 2.72$ \\
\hline
\end{tabular}

the mean value $(\mathrm{n}=6) \pm$ standard deviation

Table 3. Bioaccumulation factor (BF), enrichment factor (EF) and apsorption coefficient (AC) of Artemisia alba

\begin{tabular}{ccccc}
\hline METAL & $\boldsymbol{B F}$ & $\boldsymbol{E F}$ stem & EFleaf & $\boldsymbol{A C}$ \\
\hline $\mathbf{C a}$ & 4.57 & 3.07 & 6.62 & 4.75 \\
$\mathbf{M g}$ & 0.04 & 0.06 & 0.15 & 0.08 \\
$\mathbf{M n}$ & 0.07 & 0.04 & 0.10 & 0.07 \\
$\mathbf{F e}$ & 0.01 & 0.01 & 0.01 & 0.01 \\
$\mathbf{Z n}$ & 0.50 & 0.80 & 1.24 & 0.84 \\
$\mathbf{N i}$ & 0.04 & 0.04 & 0.10 & 0.06 \\
$\mathbf{C r}$ & 0.01 & 0.01 & 0.02 & 0.01 \\
\hline
\end{tabular}

In our study, the value of AC (also known as the plant uptake factor) was between 0.01-4.75 (Table 3), where almost all the metals showed the $\mathrm{AC}<1$ (except for $\mathrm{Ca}$ ), with the minimum value for $\mathrm{Fe}$ and $\mathrm{Cr}(\mathrm{AC}$ was 0.01$)$. The $\mathrm{BF}$ for $\mathrm{Ca}$ was with the maximum value (4.75).

The TF or mobilization ratio was assessed for determination of the relative translocation of metals from underground organs to aboveground organs (stem, leaf) of plant species (Table 4). The TF>1 at stem of species A. alba was found for $\mathrm{Ca}, \mathrm{Mn}$ and $\mathrm{Zn}$. Also, $\mathrm{TF}>1$ for $\mathrm{Mg}, \mathrm{Mn}, \mathrm{Zn}$ and $\mathrm{Ni}$ was established at investigated species at leaf.

Table 4. The translocation factor (TF) and ratios of the investigated metals content (leaf / stem and aboveground organs / underground organs) of Artemisia alba.

\begin{tabular}{ccccc}
\hline METAL & TFstem & TFleaf & leaf/stem & above/under \\
\hline $\mathbf{C a}$ & 8.05 & 0.13 & 0.02 & 0.09 \\
$\mathbf{M g}$ & 0.75 & 1.01 & 1.35 & 0.01 \\
$\mathbf{M n}$ & 1.22 & 1.56 & 1.28 & 0.06 \\
$\mathbf{F e}$ & 0.55 & 0.53 & 0.97 & 0.01 \\
$\mathbf{Z n}$ & 1.14 & 1.68 & 1.47 & 0.07 \\
$\mathbf{N i}$ & 0.72 & 1.08 & 1.51 & 0.04 \\
$\mathbf{C r}$ & 0.50 & 0.48 & 0.97 & 0.06 \\
\hline
\end{tabular}




\section{DISCUSSION}

Serpentine soils containing high levels of potentially phytotoxic elements such as $\mathrm{Ni}$, $\mathrm{Cr}$, $\mathrm{Co}$ and sometimes $\mathrm{Mn}$ and/or $\mathrm{Cu}$, present inhospitable environment for many plant species. Besides, they have low availability of $\mathrm{Ca}$ relative to $\mathrm{Mg}$ and deficiency of some essential macronutrients such as $\mathrm{P}, \mathrm{N}$ and $\mathrm{K}$, that make them stressful for plant growth.

We found that the serpentine soil of mountain Goč contained $1109.08 \mathrm{mg} \mathrm{Ca} \mathrm{kg}^{-1}$, while species $A$. alba contained $5270.50 \mathrm{mg} \mathrm{Ca} \mathrm{kg}^{-1}$. The results of our study agree with some previous the reports (ROBINSON et al., 1997, REEVES et al., 2007), although there are some literature data about the adequate concentration of $\mathrm{Ca}$ in plant tissue from $5 \mathrm{~g} \mathrm{~kg}^{-1}$ (SHALLARI et al., 1998).

Generally, serpentinite rocks contain very high $\mathrm{Mg}(18-24 \%)$ and high $\mathrm{Fe}(6-9 \%)$ but low $\mathrm{Ca}(1-4 \%)$ and $\mathrm{Al}(1-2 \%)$ (ALEXANDER 2004). Magnesium was recognized as an essential macronutrient involved in many enzyme activities and the structural stabilization of tissues. It is particularly important to plants with $75 \%$ of leaf $\mathrm{Mg}$ involved in protein synthesis and $15-20 \%$ of total $\mathrm{Mg}$ associated with chlorophyll pigments (WANIL et al. 2016). In our study, the magnesium concentration in investigated soil was $59603.59 \mathrm{mg} \mathrm{kg}^{-1}$, while species A. alba contained $4921.83 \mathrm{mg} \mathrm{Mg} \mathrm{kg}$ - that is more than concentrations reported for 17 species belonging Artemisia order (ASHRAF et al., 2010). Mg availability by plants depends mainly on chemical and physical characteristics of soil, so some factors can lead to lower $\mathrm{Mg}$ availability, such as acidic soils with low cation exchange capacity, aluminium toxicity, heat stress, droughty soil and high levels of competing elements $\left(\mathrm{K}, \mathrm{Ca}, \mathrm{NH}_{4}, \mathrm{Na}\right)$.

Some the limiting factors that make ultramafic soils unfavourable substrates for plant growth are the low $\mathrm{Ca}: \mathrm{Mg}$ quotients (due to low $\mathrm{Ca}$ and high $\mathrm{Mg}$ ) and high heavy metal concentrations, especially Ni (BRADY et al., 2005). Our results showed low Ca:Mg ratio (0.019). Similar results were described by many authors (ROBINSON et al., 1997; SHALLARI et al., 1998). Ability of the serpentine-tolerant species to absorb quantities of Ca without taking up excessive quantities of $\mathrm{Mg}$ allows them to survive on soils with depleted levels of $\mathrm{Ca}$. There are some suggestions that the plant ability to maintain high leaf $\mathrm{Ca}: \mathrm{Mg}$ by selective translocation of $\mathrm{Ca}$ and/or inhibited transport of $\mathrm{Mg}$ from roots is a key evolutionary change needed for survival on serpentine soils (O'DELL et al., 2006).

The total content of Mn in the soil mainly originates from the parent substrate, but also by anthropogenic way (wastewater and sludge, steel industry, fertilizers). Most serpentine soils contain high levels of $\mathrm{Mn}$ in the form of oxides. The natural level of $\mathrm{Mn}$ in the soil varies widely from 10 to $9000 \mathrm{mg} \mathrm{kg}^{-1}$, and the estimated mean value of this metal in the world's land is $437 \mathrm{mg} \mathrm{kg}^{-1}$ (KABATA-PENDIAS, 2011). According to ADRIANO (2001), regular $\mathrm{Mn}$ content for most of soil types ranges from $500-1000 \mathrm{mg} \mathrm{kg}^{-1}$. However, our results presented concentration of $288.86 \mathrm{mg} \mathrm{Mn} \mathrm{kg}^{-1}$ in soil samples. Manganese ions activate numerous enzymes in plants cells, as well it is involved in the process of decomposition of water molecules with releasing the oxygen (PRASAD and FREITAS, 1999). The manganese has a range between 20 and $300 \mathrm{mg} \mathrm{kg}^{-1}$ in most plants, while its level may be as high as $1500 \mathrm{mg}$ $\mathrm{kg}^{-1}$, without harm to some plant (PAIS and JONES, 2000). Therefore, comparing our data with the previous cited, we could say that A. alba was contained lower concentration of Mn (19.43 $\mathrm{mg} \mathrm{kg}{ }^{-1}$ ). It could be explained by antagonism in uptake between $\mathrm{Fe}$ and $\mathrm{Mn}$, and with very high negative correlation in content of $\mathrm{Ca}$ and $\mathrm{Mn}$ between plant and soil. Also, some literature data indicate that normal concentrations of $\mathrm{Mn}$ in plant tissues are $10-25 \mathrm{mg} \mathrm{kg}^{-1}$, while the surplus values are in the range of 20-300 $\mathrm{mg} \mathrm{kg}^{-1}$ (HOODA, 2010).

Iron originates from primary and secondary minerals. Iron reserves in the soil are mostly of inorganic nature, so the total iron content is usually between 0.5 and $4.0 \%$. Some authors point out that the mean Fe concentration in the soil is $20000-40000 \mathrm{mg} \mathrm{kg}^{-1}$ (KABATAPENDIAS, 2011), while for others the total content of this metal in the soil ranges from 7000$55000 \mathrm{mg} \mathrm{kg}^{-1}$ (NAGAJYOTI and LEE, 2010). The iron concentration in investigated soil was 
$35709.91 \mathrm{mg} \mathrm{kg}^{-1}$. Our results agree with earlier findings that serpentine soils contain high amounts of iron (REEVES et al., 2007, BECH et al., 2008). Iron is an essential element for plants and plays an important role in numerous biological processes (photosynthesis, chloroplast construction, chlorophyll biosynthesis, redox system, etc.). The plants adopt iron in the form of ions $\mathrm{Fe}^{2+}, \mathrm{Fe}^{3+}$ and in the form of chelates. Adoption of iron as well as its mobility in plants is middling to poor, since even $80-90 \%$ of iron is firmly bound. However, in this study, the concentrations of $\mathrm{Fe}$ in investigated plant $\left(316.17 \mathrm{mg} \mathrm{kg}^{-1}\right)$ is in accordance with previous cited.

The zinc is distributed evenly in the Earth's crust. The main sources of soil pollution with $\mathrm{Zn}$ are mines and iron foundries, the use of waste sludges, composted materials, pesticides and fertilizers. The most important land component that contributes to the adsorption of $\mathrm{Zn}$ is the colloidal soil fraction (minerals of clay, organic matter, hydrated metal oxides). In the soil, $\mathrm{Zn}$ is unevenly distributed in respect of its content with an interval of 10$300 \mathrm{mg} \mathrm{kg}^{-1}$ and an average value of $50 \mathrm{mg} \mathrm{kg}^{-1}$ (PAVLOVIC, 2016). According to other authors, the mean value of $\mathrm{Zn}$ content in soil of the world is $64 \mathrm{mg} \mathrm{kg}^{-1}$, while regular $\mathrm{Zn}$ content for most soil types ranges from 1-800 mg kg-1 (KABATA-PENDIAS, 2011). Therefore, comparing our data with the findings of some researches we could say that zinc content in analyzed soils ( $23.12 \mathrm{mg} \mathrm{kg}^{-1}$ ) is in accordance with previous the findings. The $\mathrm{Zn}$ content in plant samples were $19.52 \mathrm{mg} \mathrm{kg}^{-1}$. According to KABATA-PENDIAS (2011), Zn concentrations in plant tissues are in the range of $150-200 \mathrm{mg} \mathrm{kg}^{-1}$, while the surplus values in the leaves range from $27-150 \mathrm{mg} \mathrm{kg}^{-1}$.

The primary source of nickel in soil is the consumption of volcanic rock (rich in ferromagnesium minerals and sulphates, also rich in $\mathrm{Ni}$ ), but it comes also into the soil by anthropogenic activity (industry, coal and oil combustion, waste sludges, fertilizers). In our study the serpentine soils of the mountain Goč contented $931.49 \mathrm{mg} \mathrm{Ni} \mathrm{kg}^{-1}$ d.m. Therefore, our data agree with previous the reports (SHALLARI et al., 1998; REEVES et al., 2007). The Ni as an activator of the enzyme urease allows plants to utilize nitrogen from urea. There are some opinions that as $\mathrm{Ni}^{2+}$ is absorbed by roots, a diffusion depletion zone is formed in the rhizosphere and $\mathrm{Ni}^{2+}$ is released from solid or soluble bound forms to maintain soil solution equilibria (FELLET et al., 2009). According to some studies the normal plants and crop species generally contain 1-5 mg Ni kg ${ }^{-1}$ (BROOKS, 1987; CHANEY et al., 2008.) and suffer from significant phytotoxicity below $100 \mathrm{mg} \mathrm{Ni} \mathrm{kg}{ }^{-1}$. In our study the Ni content in A. alba was higher than normal values in plants $\left(53.98 \mathrm{mg} \mathrm{kg}^{-1}\right)$. These observations agree with those obtained by other authors (ZAYED and TERRY, 2003) who found that Ca:Mg quotient is a relatively important factor in Ni uptake. There are some reports about interactions between $\mathrm{Ca}, \mathrm{Mg}$ and $\mathrm{Ni}$ in plants. So, in plants, $\mathrm{Ni}^{2+}$ may competitively inhibit the uptake of divalent cations such as $\mathrm{Ca}^{2+}, \mathrm{Mg}^{2+}, \mathrm{Fe}^{2+}$ and $\mathrm{Zn}^{2+}$ that can lead to characteristic plant chlorosis symptom and consequently reduced efficiency of photosynthesis (TAPPERO et al., 2007).

The origin of $\mathrm{Cr}$ in soil is due to its presence in the parent substrate. Also, a large part of $\mathrm{Cr}$ flows into the soil anthropogenically (agricultural material, atmospheric deposits, sludge, industry). According to some authors, the average content of $\mathrm{Cr}$ in the earth's soil is $40 \mathrm{mg} \mathrm{kg}^{-1}$ (ADRIANO, 2001), while others report that this content is $54 \mathrm{mg} \mathrm{kg}^{-1}$ (KABATAPENDIAS, 2001). The results of this study indicate that the content of $\mathrm{Cr}$ in the test soil has exceeded the literature data $\left(485.24 \mathrm{mg} \mathrm{Cr} \mathrm{kg}^{-1}\right)$. The chromium is the contaminant with highest total contents in soils, but that only showed an average extractability of $0.008 \%$, and some authors (ZAYED and TERRY, 2003) have found that nearly all the soil Cr was in a more resistant fraction (less soluble forms). The high $\mathrm{Cr}$ concentrations in the serpentine soils often are in the form of chromite, an unalterable mineral, and so $\mathrm{Cr}$ remains not bioavailable. In most of the soils, $\mathrm{Cr}$ is accessible in low concentrations, so that it is present in plants in concentrations 0.2-0.4 mg kg${ }^{-1}$ (KASTORI, 1993; KASTORI et al., 1997). According to REEVES and BAKER (2000), the normal values for $\mathrm{Cr}$ in plants are in range of $0.2-5 \mathrm{mg} \mathrm{kg}^{-1}$. However, our findings were showed $\mathrm{Cr}$ concentration in the investigated plant samples of $5.78 \mathrm{mg} \mathrm{Cr}$ 
$\mathrm{kg}^{-1}$ that exceeded the concentration in the literary data. The concentrations of $\mathrm{Ni}$ and $\mathrm{Cr}$ in the investigated soil were above their the maximum allowable concentration in the soil, as well as limit and remediation values, according to regulation of Republic of Serbia (ANONYMOUS, 1997; ANONYMOUS, 2010). Also, the Ni concentration was above the limit value for the given metal in the soil according to the European Union Directive (EU Directive 86/278/EEC, 1986).

The current study showed different heavy metal concentration in investigated plant species, depending on kind of metal and organ. In soil samples metal concentrations had order: $\mathrm{Mg}>\mathrm{Fe}>\mathrm{Ca}>\mathrm{Ni}>\mathrm{Cr}>\mathrm{Mn}>\mathrm{Zn}$, and in the plant $\mathrm{Ca}>\mathrm{Mg}>\mathrm{Fe}>\mathrm{Ni}>\mathrm{Zn}>\mathrm{Mn}>\mathrm{Cr}$. The $\mathrm{Ca}: \mathrm{Mg}$ ratio in soil samples was 0.019 and in plant samples 1.07. Also, in the leaves of species $A$. $a l b a$, the highest content of almost all investigated metals (except Fe) was determined, while the stem of this species contained the highest Fe. It has been shown that the roots of the $A$. alba species have better accumulation of the examined metals than the aboveground organs, and that the leaves have a higher accumulation capacity of $\mathrm{Mg}, \mathrm{Mn}, \mathrm{Zn}$ and $\mathrm{Ni}$ than the stem of the studied plant. Metal uptake by plants depends on the bioavailability of the metal in soils, which in turn depends on the retention time of the metal, as well as the interaction with other elements and substances. Also, metal phytoavailability depends on the form of the element in soil and on the considered plant species. However, it was found that the metal uptake does not necessarily correlate with metal content in the soil, probably because of diverse metal uptake mechanisms and to some disparities in their transport properties, resulting in differences in the metal concentrations in plants (GREGER, 2004).

Tolerance of plants to metals can be constitutive tolerance, acquired during phylogenesis or induced tolerance that represents stressful adaptation, response to adverse environmental conditions. Depending on location where metal tolerance mechanisms work, we can split them into external (apoplastic) and internal (simplastic). The external mechanism of plant tolerance to metals is based on the binding of metals in the cell wall $(\mathrm{Zn}, \mathrm{Cu}, \mathrm{Pb})$, secretion of organic acids and chelates over the root into the external environment, the establishment of $\mathrm{pH}$ and redox barriers and others. The internal mechanisms of plant tolerance to metals is based on the creation of a complex of metals with proteins (metallothioneins), peptides (phytohelatins), organic acids (malic acid, citric acid), accumulation in vacuoles (compartmentation in the form of soluble and insoluble complexes) after their entry into the cell. Sequestration of metal in tissues or cellular compartments (vacuole), the translocation of excess metals into older leaves prior to their decay can be a mechanism of the tolerance of less sensitive plants to metals.

\section{CONCLUSIONS}

This study was carried out on endemic obligate serpentinophyte Artemisia alba Turra., which lives on serpentine area in the Central part of Serbia. The aim of this research was to determine the its capacity for bioaccumulation, translocation and phytoremediation of some metals ( $\mathrm{Ca}, \mathrm{Mg}, \mathrm{Mn}, \mathrm{Fe}, \mathrm{Zn}, \mathrm{Ni}$ and $\mathrm{Cr}$ ). The concentrations of $\mathrm{Ni}$ and $\mathrm{Cr}$ in the investigated soil were above their maximum allowable concentration in the soil, also above their limit and remediation values in the soil, according to regulation of Republic of Serbia. Also, the Ni concentration was above the limit value for the given metal in the soil according to the EU Directive (1986). In soil samples metal concentrations had order: $\mathrm{Mg}>\mathrm{Fe}>\mathrm{Ca}>\mathrm{Ni}>\mathrm{Cr}>\mathrm{Mn}>\mathrm{Zn}$ and in the plant $\mathrm{Ca}>\mathrm{Mg}>\mathrm{Fe}>\mathrm{Ni}>\mathrm{Zn}>\mathrm{Mn}>\mathrm{Cr}$. The results of our study showed that the concentrations of all examined metals were higher in soil than in plant (excepting $\mathrm{Ca}$ ). The general trend of metal accumulation in soil was: $\mathrm{Mg}>\mathrm{Fe}>\mathrm{Ca}>\mathrm{Ni}>\mathrm{Cr}>\mathrm{Mn}>\mathrm{Zn}$. On the other hand, A. alba has different ability for metal accumulation $(\mathrm{Ca}>\mathrm{Mg}>\mathrm{Fe}>\mathrm{Ni}>\mathrm{Zn}>\mathrm{Mn}>\mathrm{Cr})$. Almost all the metals showed the $\mathrm{BCF}<1$ (except for $\mathrm{Ca}$ ). Our study exhibited different heavy metal concentration in investigated plant species, depending on kind of metal and plant organ. 
The metal uptake does not necessarily correlate with metal content in the soil. The results of this study indicate the good absorption of $\mathrm{Ca}$ and its translocation through the stem to the leaves of the studied plant. Good translocation of $\mathrm{Mn}$ and $\mathrm{Zn}$ through stem and leaves of the species A. alba was also demonstrated, as well as the translocation and accumulation of $\mathrm{Mg}$ and $\mathrm{Ni}$ in the leaves of the investigated plant.

Based on the values of $\mathrm{BF}$ and $\mathrm{TF}$, the species $A$. alba can be considered a potential candidate for the phytoextraction of soil contaminated with $\mathrm{Ca}, \mathrm{Mg}, \mathrm{Mn}, \mathrm{Zn}$ and Ni. It has also been found that the leaves of the studied species can be used in the phytoremediation of soil loaded with $\mathrm{Zn}$.

\section{Acknowledgments}

This investigation was supported by the Ministry of Science and Tehnological Development of the Republic of Serbia (BTR 41010). The authors are thankful to colleagues from Geological Bureau of Serbia.

\section{References:}

[1] AdRIANO, D.C. (2001): Trace element in terrestrial environments: biogeochemistry, bio-availability and risks of metals. Springer, New York.

[2] AleXANDER, E.B. (2004): Serpentine soil redness, differences among peridotite and serpentinite materials, Klamath Mountains, California. International Geology Review 46(8): 754-764. doi: 10.2747/0020-6814.46.8.754

[3] ANONYMOUS (1997): Pravilnik o dozvoljenim količinama opasnih i štetnih materija u zemljištu i vodi za navodnjavanje i metodama njihovog ispitivanja. Službeni glasnik $R S$, br. $18 / 97$.

[4] ANONYMOUS (2010): Uredba o programu sistemskog praćena kvaliteta zemljišta, indikatorima za ocenu rizika od degradacije zemljišta i metodologiji za izradu remedijacionih programa. Službeni glasnik RS, br. 88/2010, prilog 3 .

[5] Ashraf, M., HAYAT, M.Q., MumtaZ, A.S. (2010): A study on elemental contents of medicinally important species of Artemisia L. (Asteraceae) found in Pakistan. Journal of Medicinal Plants Research, 4(21): 2256-2263.

[6] Bani, A., Pavlova, D., Echevarria, G., Mullaji, A., Reeves, R., Morel, J.L., SulçE, S. (2010): Nickel hyperaccumulation by the species of Alysssum and Thlaspi (Brassicaceae) from the ultramafic soils of the Balkans. Botanica Serbica, 34(1): 3-14.

[7] Bech, J., Tume, P., Longan, L., Reverter F., Bech, J., Tume, L., Tempio, M. (2008): Concentration of $\mathrm{Cd}, \mathrm{Cu}, \mathrm{Pb}, \mathrm{Zn}, \mathrm{Al}$, and $\mathrm{Fe}$ in soils of Manresa, NE Spain. Environmental Monitoring and Assessment 145: 257-266. doi: 10.1007/s10661-007-0035-2

[8] Brady, K.U., Kruckeberg, A.R., Bradshaw, H.D. (2005): Evolutionary ecology of plant adaptation to serpantine soils. The Annual Review of Ecology, Evolution, and Systematics 36: 243-266. doi: 10.1146/annurev.ecolsys.35.021103.105730

[9] Branković, S., Glišić, R., Topuzović, M., Marin, M. (2015): Uptake of seven metals by two macrophytes species: potential for phytoaccumulation and phytoremediation. Chemistry and Ecology, 31(7): 583-593. doi: 10.1080/02757 540.2015.1077812

[10] BRoOKS, R.R. (1987): Serpentine and its Vegetation: A Multidisciplinary Approach. Dioscorides Press, Portland, Oregon, 454 p. 
[11] Chaney, R.L., Chen, K.Y., Li, Y.M., Angle, J.S., BAKer, A.J.M. (2008): Effects of calcium on nickel tolerance and accumulation in Alyssum species and cabbage grown in nutrient solution. Plant Soil 311: 131-140. doi: 10.1007/s11104-008-9664-7

[12] ECHEVARRIA, G. (2018): Genesis and Behaviour of Ultramafic Soils and Consequences for Nickel Biogeochemistry. In: Van der Ent A., Echevarria G., Baker A., Morel J. (eds), Agromining: Farming for Metals. Mineral Resource Reviews. Springer, Cham.

[13] EU DiReCTIVE 86/278/EEC (1986): Directive 86/278/EEC on the protection of the environment and in particular of the soil, when sewage sludge is used in agriculture. The Official Journal of the European Union, L181/6.

[14] Fellet, G., Centofanti, T., Chaney, R.L., Green, C.E. (2009): NiO(S) (bunsenite) is not available to Alyssum species. Plant and Soil 319: 219-223. doi: 10.1007/s11104008-9863-2

[15] Freitas, H., Prasad, M.N.V., Pratas, J. (2004): Analysis of serpentinophytes from North-East of Portugal for trace metal accumulation-relevance to the management of mi-ne environment. Chemosphere 54: 1625-1642. doi: 10.1016/ j.chemosphere.2003.09.045

[16] GHosh, M., Singh, S. P. (2005): A comparative study of cadmium phytoextraction by accumulator and weed species. Environmental Pollution 133: 365-371. doi: 10.1016/ j.envpol.2004.05.015

[17] GREGER, M. (2004): Metal availability, uptake, transport and accumulation in plants. In: Prasad M.N.V. (ed.), Heavy metal stress in plants: from biomolecules to ecosystems, $2^{\text {nd }}$ ed., Springer- Verlag, Berlin Heidelberg, 1-27 pp.

[18] Gupta, S., NayeK, S., Saha, R.N., SAtpati, S. (2008): Assessment of heavy metal accumulation in macrophyte, agricultural soil and crop plants adjacent to discharge zone of sponge iron factory. Environmental Geology 55: 731-739. doi: 10.1007/ s00254-007-1025-y

[19] HoodA, S.P. (2010): Trace elements in soil. Kingston University London, A.John Wiley and Sons Ltd Blackwell Publishing, London.

[20] JAVORKA, S., CSAPODY, V. (1979): Iconographia Florae parties Austro-Orientalis Europae Centralis, Academiai kido, Budampest.

[21] Josifović, M. (1991): Flora of Serbia, vol. I, SAAS, Beograd.

[22] Kabata-Pendias, A. (2001): Trace Elements in Soil and Plants, (2 ${ }^{\text {nd }}$ ed.), Boca Raton, CRC press, Washington, D.C.

[23] Kabata-Pendias, A. (2011): Trace Elements in Soil and Plants $\left(4^{\text {th }}\right.$ ed.), Boca Raton, CRC press, Washington, D.C.

[24] KASTORI, R. (1993): Teški metali i pesticidi u zemljištu Vojvodine. Poljoprivredni fakultet, Institut za ratarstvo i povrtarstvo, Novi Sad.

[25] Kastori, R., Vukmirović, Z., Polić, P., Blagojević, S., Bogdanović, D., Ubavić, M., Hadžić, V., Govedarica, M., Milosević, N., JaraK, M., Petrović, N., ArseniJeViĆ-MAKSiMOVIĆ, I., VAPA, M., VAPA, LJ. (1997): Heavy metals in the environment, Insitute of field and vegetable crop, Novi Sad, Serbia.

[26] Nagajyoti, P.C, LeE, K.D., SReeKanth T.V.M. (2010): Heavy metals, occurrence and toxicity for plants: a review. Environmental Chemistry Letters 8(3): 199-216. doi: 10.1007/s10311-010-0297-8 
[27] O’Dell, R.E., James, J.J., RichardS, J.H. (2006): Congenetic serpentine and nonserpentine shrubs differ more in leaf Ca: $\mathrm{Mg}$ than in tolerance of low $\mathrm{N}$, low $\mathrm{P}$ or heavy metals. Plant and Soil 280: 49-64. doi: 10.1007/s11104-005-3502-y

[28] Pais, I., Jones, J.B. (2000): The Handbook of Trace Elements, St. Luice Press, Florida.

[29] Prasad, M.N.V., Freitas, H.M.D.O. (1999): Feasible biotechnological and bioremediation strategies for serpentine soils and mine spoils. Electronic Journal of Biotechnology 2(1): 20-34. doi: 10.2225/vol2-issue1-fulltext-5

[30] Pavlović, P., Mitrović, M., ĐorĐević, D., Sakan, S., Slobodnik, J., LišKa, I., Csanyi, B., Jarić, S., Kostić, O., Pavlović, D., Marinković, N., Tubić, B., PAUNOVIĆ, M. (2016): Assesment of the concentration od riparian soil and vegetation by trace metals - A Danube river case study. The Science of Total Environment 540: 396-409. doi: 10.1016/j.scitotenv.2015.06.125

[31] ReEves, R.D., BAKER, A.J.M. (2000): Phytoremediation of toxic metals. In: Raskin, I, Ensley, B.D.(eds.) Using plants to clean up the environment, Wiley and Sons, NY

[32] Reeves, R.D., BAKer, A.J.M., Becquer, T., Echevarria, G., Miranda, Z.J.G. (2007): The flora and biogeochemistry of the ultramafic soils of Goiás state, Brazil. Plant Soil 293: 107-119. doi: 10.1007/s11104-007-9192-x

[33] Robinson, B.H., Chiarucci, A., Brooks, R.R., Petit, D., Kirkman, J.H., GregG, P.E.H., DE DOMINICIS, V. (1997): The nickel hyperaccumulator plant Alyssum bertolonii as a potential agent for phytoremediation and phytomining of nickel. Journal of Geochemical Exploration 59: 75-86. doi: 10.1016/S0375-6742(97)00010-1

[34] Shallari, S., Schwartz, C., Hasko, A., Morel, J.L. (1998): Heavy metals in soils and plants of serpentine and industrial sites of Albania. The Science of Total Environment 209: 133-142.

[35] Stevanović, V., TAN, K., IAtrou, G. (2003): Distribution of the endemic Balkan flora on serpentine I.- obligate serpentine endemics. Plant Systematics and Evolution 242: 149-170. doi: 10.1007/s00606-003-0044-8

[36] Tappero, R., Peltier, E., Gräfe, M., Heidel, K., Ginder-Vogel, M., Livi, K.J.T., Rivers, M.L., Marcus, M.A., Chaney, R.L., Sparks, D.L. (2007): Hyperaccumulator Alyssum murale relies on a different metal storage mechanism for cobalt than for nickel. New Phytologist 175(4): 641-654. doi: 10.1111/j.1469-8137.2007.02134.x

[37] TATiĆ, B., Veljović, V. (1992): Distribution of serpentinized massive on the Balkan peninsula and their ecology. In: Roberts B.S. and Proctor J. (eds.) The ecology of areas with serpentinized rock: A world view, Kluwer Academic, Dordrecht, 199-215

[38] Tutin, T.G., Heywood, V.H., Burges, N.A., Moore, D.M., Valentine, D.H., WAlters, S.M., WeBB, D.A. (1976): Flora Europaea. vol4. Plantaginaceae to Compositae (and Rubiaceae) Cambridge University Press. doi: 10.5281/ zenodo. 293764

[39] Valles, J., Torrell, M., Garnatje, T., Garcia-Jacas, N., Vilatersana, R., SusannA, A. (2003): The genus Artemisia and its allies: phylogeny of the subtribe Artemisiinae (Asteraceae, Anthemideae) based on nucleotide sequences of nuclear ribosomal DNA internal transcribed spacers (ITS). Plant Biology 5(3): 274-284. doi: $10.1055 / \mathrm{s}-2003-40790$

[40] Wanil, G., NAZIM, H., Liang, Z., YANG, D. (2016): Magnesium deficiency in plants: An urgent problem. The Crop Journal 4: 83-91. doi: 10.1016/j.cj.2015.11.003

[41] Zayed, A., TerRy, N. (2003): Chromium in the environment: factors affecting biological remediation. Plant and Soil 249: 139-156. doi: 10.1023/A:1022504826342 